\title{
The Effectiveness of Consumption between Temulawak Extract (Curcuma xanthorrhiza) and Katuk Leaves (Sauropus androgynous) towards Breast Milk Launch in Postpartum Mothers
}

\author{
Mayasari Putri Ardela, Siti Aminah, Supraptiningsih, Faradilla Kartika Nuvitaningrum, Anis \\ Yuliana \\ Midwifery Proffesion Program, Faculty of Health Science, Kadiri University, Indonesia \\ Email: mayasari.ardela@unik-kediri.ac.id
}

ARTICLE INFO

Article history:

Received: March 8, 2021

Revised: April 24, 2021

Accepted: May 12, 2021

Keywords:

Temulawak extract,

Katuk leaves,

Breast milk,

Postpartum.
ABSTRACT

Breast milk is the natural first food for babies. Its provides all the energy and nutrients for babies in the first months of life. Breastfeeding is an excellent way of providing ideal food for the healthy growth and development of babies. Efforts to increase breast milk production are by consuming foods or ingredients that are believed to increase milk production. Temulawak (Curcuma xanthorrhiza) contains essential oils that can Temulawak contains essential oils that can stimulate breast milk production. In addition, katuk leaves (Saoropus androgynus) also have the same effect on milk production. The purpose of this study was to determine the difference in the effectiveness of consumption of temulawak extract and katuk leaves on the breast milk's flow in postpartum mothers. This research is a pre-experimental type with a two group pretestposttest approach to 16 postpartum mothers who experience problems with the smooth flow of breast milk in each group. The results of the study were analyzed using the Mann Whitney test with p-value $>(0.05)$, which means that there is no difference in the effectiveness of consuming temulawak extract and katuk leaves on the smooth flow of breast milk in postpartum mothers. 


\section{Introduction}

Breast milk is a complete source of nutrition for babies, increases endurance, increases intelligence, creates a sense of affection between mother and child, supports personality development and emotional intelligence, contains fatty acids needed for brain growth so babies are smarter [1]. The United Nations Children's Fund (UNICEF) estimates that exclusive breastfeeding for 6 months can prevent the death of 1.3 million children under five. However, in Indonesia, only about $8 \%$ of mothers give exclusive breastfeeding to their babies until they are 6 months old [2].

Based on data from the East Java Provincial Health Office in 2019, the number of babies who received exclusive breastfeeding was $64.08 \%$. The coverage of babies who received exclusive breastfeeding in 2013 was $62.52 \%$ of the 702.769 babies [3]. Meanwhile, based on data from the Kediri District Health Office, in 2019 out of a total of 3.838 babies, only 2.535 babies were exclusively breastfed (66.4\%) while the target of the service itself was $89 \%$ [4].

The low level of exclusive breastfeeding is one of the triggers for the low nutritional status of infants and toddlers. The most important thing to increase the supply of breast milk is to breastfeed the baby more often, because when the baby starts to suckle, the stimulation of sucking on the nipple causes prolactin to be released from the pituitary so that milk secretion becomes smoother [5].

The right way to increase breast milk production is to consume foods or herbs that are believed to increase milk production. Temulawak (Curcuma xanthorrhiza) is one of the plants that is believed to be able to facilitate the production of breast milk because it contains essential oils that can facilitate the release of breast milk [6]. In addition, katuk leaves (Saoropus androgynus) are also believed to help increase breast milk production. Katuk leaves are rich in nutritional content compared to papaya leaves and leaves, so it is very potential to be used as a natural treatment ingredient [2].

Based on the above phenomenon, the researchers are interested in conducting experiments on the differences in the effectiveness of consumption of temulawak extract and katuk leaves on the smooth production of breast milk in postpartum mothers so that they can be used in policies that support efforts to improve the quality of breast milk production.

\section{Method}

\section{A. Design and Samples}

The research was carried out in the working area of the Ngadiluwih Public Health Center, Kediri Regency, East Java in December 2020. This study is a pre-experiment with two groups pretestposttest. The sampling technique was carried out using purposive sampling with a total sample of 32 postpartum mothers who were divided into 2 groups, 16 women consuming temulawak extract and 16 other women consuming katuk leaves.

\section{B. Data Collections}

Respondents who were selected were postpartum who had problems with the smooth flow of breast milk from day 3 to day 42. Researchers observed the smooth flow of breast milk before the intervention was given. The treatment group was divided into 2, namely treatment group 1 (P1) which consumed temulawak extract and treatment group 2 (P2) which consumed boiled water from katuk leaves. Each group consumed temulawak extract and boiled water from katuk leaves for a week. Then the researchers conducted post-intervention observations and compared the results.

\section{Data Analysis}

The analyzed data used to test the hypothesis is the Mann Whitney test. All tests are done by using SPSS for Windows 24. 


\section{Results and Discussion}

The results of this study indicate that the benefits of consuming temulawak extract and boiled water from katuk leaves affect the smoothness of breast milk. Initially, all respondents had problems with the smooth flow of breast milk. Then after being given an intervention for a week in the form of consuming temulawak extract and boiled water from katuk leaves, it was proven to be able to overcome the problem of smooth breastfeeding in both groups.

Table 1. The effectiveness of consumption of temulawak extract and boiled water of katuk leaves on the smooth production of breast milk in postpartum mothers

\begin{tabular}{ccccc}
\hline \multirow{2}{*}{ Intervention Group } & \multicolumn{3}{c}{ Breast Milk Flow Smoothened } \\
\cline { 2 - 5 } & \multicolumn{2}{c}{ Before Intervention } & \multicolumn{2}{c}{ After Intervention } \\
\cline { 2 - 5 } & Total & \% & 0 & \%olal \\
\hline Temulawak extract & 0 & 0 & 15 & 93.75 \\
\hline Katuk leaves & 0 & & 15 & 93.75 \\
\hline
\end{tabular}

Based on table 1, using Wilcoxon test, the p-value $<(\alpha=0.05)$. So it can be interpreted that the consumption of temulawak extract and boiled water of katuk leaves is effective for launching breast milk in postpartum mothers.

Table 2. The result of difference test beetwen treatment group 1 (P1) which consumed temulawak extract and treatment group $2(\mathrm{P} 2)$ which consumed boiled water from katuk leaves

\begin{tabular}{ccc}
\hline Intervention Group & Mean & P value \\
\hline P1 & 16.50 & $1.000>\alpha$ \\
P2 & 16.50 & \\
\hline
\end{tabular}

Based on table 1, it can be interpreted that the distribution of statistical using Mann Whitney test, the results on differences in the effectiveness of consumption of temulawak extract and boiled water of katuk leaves on the smooth flow of breast milk shows that there is no significant difference as evidenced by the $\mathrm{p}$ value $>\alpha$.

Temulawak is a member of the Zingiberaceae family which is aromatic, sharp and slightly spicy. One of its properties is to stimulate and increase breast milk [7]. Other studies have shown that plants that are efficacious for increasing milk secretion may contain active ingredients that work such as Prolactin Releasing Hormone (PRH), contain active ingredients of steroid compounds, contain active ingredients that are efficacious such as prolactin and contain active ingredients that are efficacious such as oxytocin. Temulawak contains almost all of these substances [8].

Increased milk production is also stimulated by the hormone oxytocin. The cytosine hormone is influenced by the polyphenols present in katuk leaves. This increase in hormones will make breast milk flow more profusely than usual [9]. Katuk leaves are useful as a source of nutrients and antioxidants. The content of katuk leaves includes phytochemical compounds such as saponins, flavonoids, and tannins, isoflavonoids that resemble estrogen. In addition, katuk leaves also contain a type of substance that functions as a laktagogum which is useful for facilitating breast milk production. The content of alkaloids and sterols from katuk leaves can increase milk production to be more because it can increase glucose metabolism for lactose synthesis so that milk production increases [10].

According to the researcher, from the results of the explanation above, the extracts of temulawak and katuk leaves can be used as alternatives that have the same efficacy, namely to expedite the release of breast milk in postpartum mothers. 


\section{Conclusion}

The results of this study showed that the benefits of consuming ginger extract and water decoction of the leaves katuk affect the smoothness of milk. Extracts of ginger leaves and leaf katuk can equally be used as an alternative that has the same properties that facilitate the release of breastfeeding on postpartum mothers who have problems with breastfeeding, especially problems smoothness milk.

\section{Acknowledgment}

The author is thankful to Ngadiluwih Public Health Center, Kediri Regency, East Java respondents for their valuable information and their awareness to participate in this research.

\section{References}

[1] Anggraeni, Yetti. Asuhan Kebidanan Masa Nifas. Yogyakarta: Pustaka Rihama. 2010.

[2] Sujiyatini, Djanah N., and Ana Kurniati. Asuhan Ibu Nifas. Yogyakarta: Cyrillus Publisher. 2010.

[3] Dinkes Jatim. Profil Kesehatan Provinsi Jawa Timur Tahun 2012. Surabaya: Dinas Kesehatan Provinsi Jawa Timur. 2013

[4] Dinkes Kota Kediri. Profil Kesehatan Kota Kediri Tahun 2013. Kediri: Dinas Kesehatan Kota Kediri. 2014.

[5] Asydhad, Amalia. Makanan Tepat Untuk Balita. Tangerang: Kawan Pustaka. 2006.

[6] Subagja, Hamid Prasetya. Temulawak itu Ajaib. Yogyakarta: Flash Books. 2010.

[7] Hariana, H. Arief. 262 Tumbuhan Obat dan Khasiatnya. Jakarta: Penebar Swadaya Grup. 2013.

[8] Muhammad, Gunawan, Agus Djamaluddin, and Farhan Farhan. "PEMBUATAN DAN UJI ORGANOLEPTIK SEDIAAN SERBUK INSTAN DAUN KATUK (Sauropus androgynus-(L) Merr) DAN TEMULAWAK (Curcuma xanthorrhiza Roxb)." Journal of Holistic and Health Sciences 2.2 (2018): 56-59.M. Young, The Technical Writer's Handbook. Mill Valley, CA: University Science, 1989.

[9] Rahmanisa, Soraya, and Tara Aulianova. "Efektivitas Ekstraksi alkaloid dan sterol daun katuk (Sauropus androgynus) terhadap produksi ASI." Jurnal Majority 5.1 (2016): 117-121.

[10] Juliastuti, Juliastuti. "Efektivitas Daun Katuk (Sauropus Androgynus) Terhadap Kecukupan Asi Pada Ibu Menyusui Di Puskesmas Kuta Baro Aceh Besar." Indonesian Journal for Health Sciences 3.1 (2019): $1-5$. 